\title{
The Development of Siberia: the Yenisei (Oxford) Expedition of 1914-1915
}

\author{
Elena I. Maizik* and Alexandr S. Vdovin \\ Krasnoyarsk State Pedagogical University \\ named after V.P. Astafiev \\ 89 Ada Lebedeva Str., Krasnoyarsk, 660049, Russia
}

Received 27.07.2018, received in revised form 05.09.2018, accepted 10.09.2018

The study is devoted to the English explorer of the indigenous peoples of the Yenisei North, Marie Czaplicka, and Henry Hall, who became her companion and anthropologist in the Yenisei (Oxford) expedition. She is a young Polish woman who went to Siberia as the head of the expedition, as a result of which she wrote a valuable book on this topic. Czaplicka became the first woman professor at Oxford University. She worked in London and traveled around Siberia, conducting extensive field research in the era when women were not engaged in scientific research or expeditions at all. She was also an experienced photographer. The personality of Marie Czaplicka is unique. Her works remain relevant. Foreign scientists have turned to her studies for more than a hundred years, but she is little known in modern Russia, though she was born and lived most of her life in the Russian Empire. The authors refer to the personality of Marie Czaplicka and her works. The aim of the work is to determine the significance of the research of the Yenisei expedition. The collections picked up during the expedition are stored in the Museum of Archeology and Anthropology of the University of Pennsylvania and the Pitt Rivers Museum of Ethnography and Archeology and comprise about 600 items of ethnography, archeology and images. The research of M. Czaplicka is a contribution to the ethnography of Siberia.

Keywords: ethnography, anthropology, the Yenisei expedition, indigenous peoples of Siberia, Marie Czaplicka, Henry Hall.

The publication was carried out with the financial support of Krasnoyarsk Regional Fund for Support of Scientific and Technical Activity and Russian Foundation for Basic Research, project No. 16-11-24009 a(p) - Turukhansk Territory: exploration and study in the late $18^{\text {th }}$ early $20^{\text {th }}$ century.

Research area: history.

Citation: Maizik, E.I., Vdovin, A.S. (2018). The development of Siberia: the Yenisei (Oxford) expedition of 1914-1915. J. Sib. Fed. Univ. Humanit. soc. sci., 11(9), 1440-1452. DOI: 10.17516/1997-1370-0314.

(C) Siberian Federal University. All rights reserved

* Corresponding author E-mail address: mayzikei@mail.ru

This work is licensed under a Creative Commons Attribution-NonCommercial 4.0 International License (CC BY-NC 4.0). 
Marie Czaplicka is known as a British ethnographer of Polish descent, an anthropologist, a geographer, a researcher of the Siberian North. The fact that she started her scientific activity as a specialist in the field of studying Central Asia, made the only major expedition to Siberia, where she realized the knowledge obtained in the university in practice and gained experience in the field, gathered a lot of new knowledge for the British ethnographic science, is very important. The personality of the researcher also deserves special attention.

Marie Antoinette Czaplicka was born on October 25, 1884 in Warsaw, where she graduated from high school and began to study pedagogy. In 1910, she went to continue her studies in England, where she worked under the guidance of the ethnographer C.G. Seligman at the Department of Anthropology, London School of Economics and Political Science, then at Somerville College, Oxford, and two years later received a doctorate degree in anthropology (Kubica, 2015: 13-14).

Marie wrote about her first distant impressions of Siberia, "When I was a child, I heard the word Siberia, it meant a certain thing for me, namely terrible unjustified human risk, painful torture of the soul, courage, luck and many independent people" (Czaplicka, 1916: 1). In many ways, she was attracted by the uncertainty, the lack of study of the region to some extent, so the indigenous peoples of the Siberian north were the subject of her scientific interests. "Are there real indigenous peoples in Siberia, like in Australia and Africa?", wrote M. Czaplicka. "This is a question that is often asked in England, and Siberia is sometimes seen as a country originally inhabited by political exiles and criminals. It has become clear only recently that, in addition to interest and liking caused by the first one, and the curiosity felt about the latter, Siberia and its people represent an interesting set of directions for studying, especially for anthropological and archaeological research" (Czaplicka, 1914: 9).

Marie kept in touch with Russian ethnographers from St. Petersburg University, corresponded to the ethnographers L.Ya. Sternberg and V.I. Jochelson, who criticized her first monograph "Aboriginal Siberia. A Study in Social Antropology", published in 1914 (Czaplicka, 1914: 9). V.I. Jochelson pointed out in the review that the work was not original, "The book of Czaplicka is a compilation work and a summary of data on the religion and sociology of Siberian aliens on the basis of works of mainly Russian authors - the works that were written in Russian with a few exceptions ... The main merit of Czaplicka is that she opened Russian sources to English anthropologists, which were inaccessible to them. We can only wish her success in her intention to continue a summary of anthropological material about Siberia in terms of material 
culture, somatology and archeology." (Quoted after Reshetov, 2010). Foreign scholars, on the contrary, noted that the work presented a full summary of materials on the topic, because the author had investigated all available literature on the indigenous peoples of Siberia. In this regard, in England, her work was a success, as the materials were first available in English, while this region was poorly researched for English anthropologists, who concentrated their research on the colonies of the British Empire (Ehrlich, 1918: 325-326). M. Czaplicka herself noted that her acquaintance with Siberia before the publication of the book had been purely theoretical, so the expedition to the north of Siberia was her dream, and seemed a logical continuation of serious scientific activity (Klitsenko, 2016).

Soon there was an opportunity for conducting field research in the Yenisei province. Due to a grant from the Pitt Rivers Museum of Ethnography and Archeology, "The Mary Ewart Traveling" scholarships for travelers and the funds collected in Somerville by Miss M.C. Scott, Oxford University and the Museum of Archeology and Anthropology of the University of Pennsylvania organized the Yenisei expedition led by Marie Czaplicka (Maria Chaplitsa explores...). The expedition also included an ornithologist Maud Doria Haviland (1889-1941) from the National Museum of Natural History in London, an American artist and traveler Dora Curtis (1875-1926) and an anthropologist from the University of Pennsylvania Henry Usher Hall (1876-1944), their translator and local guide was Vasiliy Korobeinikov (Czaplicka, 1916: 7, 22, 36).

The purpose of the expedition was the study of the indigenous peoples of the Yenisei North. The travelers left England in the spring of 1914. After traveling through Warsaw, St. Petersburg and Moscow, they traveled to Krasnoyarsk by train, from where they traveled to the north of the Yenisei province by boat (Kubica G. Marie Czaplicka - płeć, szamanizm, rasa, Biografia antropologiczna., Kraków 2015 P. 293).

The research was carried out along several routes: 1) from Krasnoyarsk to Golchikha along the Yenisei from June to September 1914; 2) from Monastyrsky village to the nomadic Evenks and then to Chirinda and Yessey to the Evenks and Yakuts in September 1914 - April 1915; 3) from Krasnoyarsk to Khakassia in June 1915 (Klitsenko, 2016) (Fig. 1).

The researchers were met and greeted in Siberia. "At the station in Krasnoyarsk, different people who knew or were informed about our arrival were waiting for us, and we faced the friendly greeting of strangers, who were strong, others were looking for the best in the rather free region of the unfamiliar country. When I returned to 


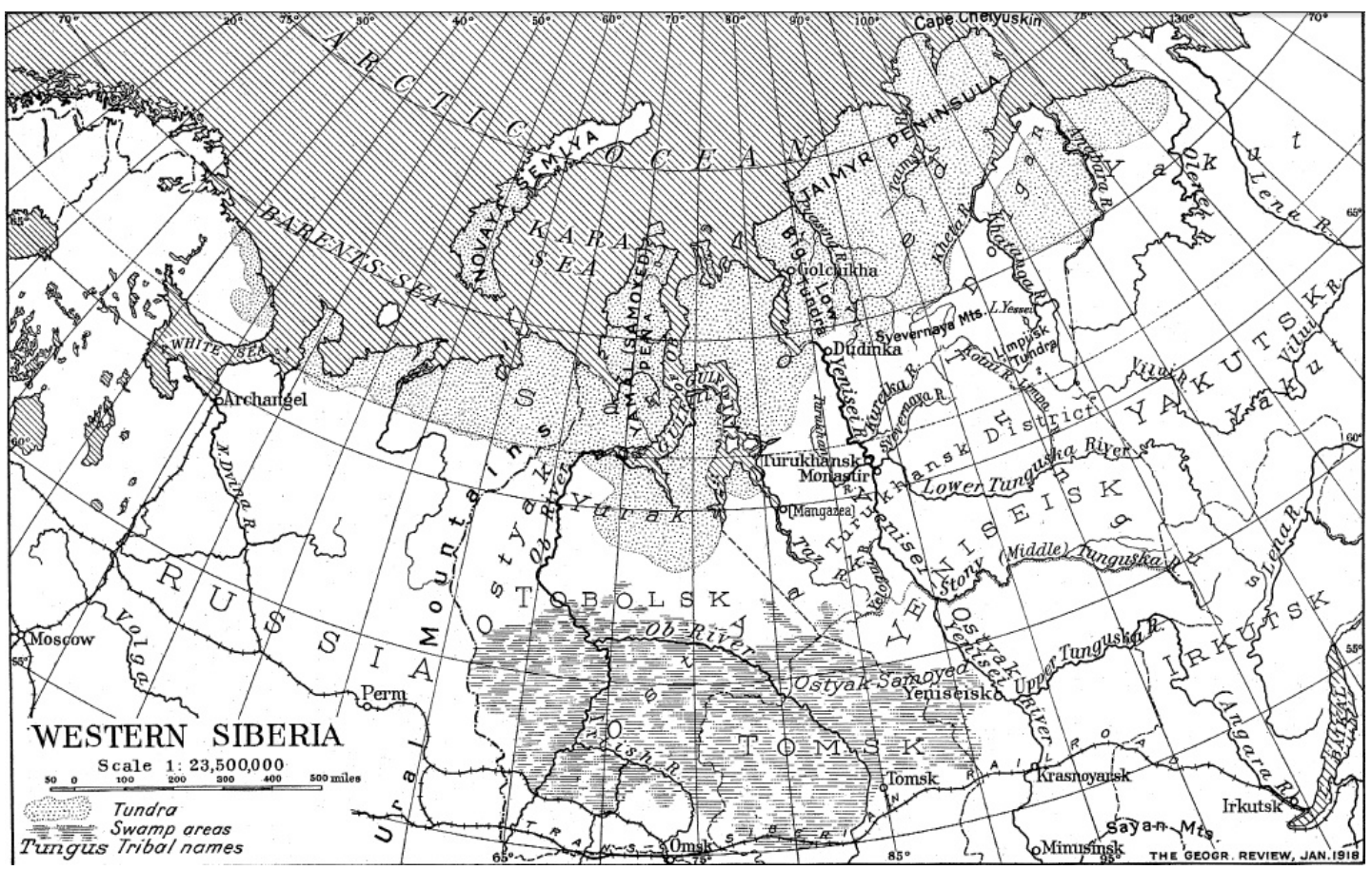

Fig. 1. The route map of the expedition (Hall, 1918: 2)

Krasnoyarsk for a long stop after a year spent in the far north, I thought about the meetings," recalled M. Czaplicka (Czaplicka, 1916: 13-14).

A participant of the expedition, Maud Haviland, also conducted ornithological studies and collections. In 1915 she published travel notes "A summer on the Yenesei" (1914), in which she presented a description of the research of the Yenisei north. From these notes we find out that the short stay of the researchers in Krasnoyarsk did not allow them to learn the city sufficiently, they did not visit the local museum, since they hurried to go north. H. Hall stayed in Krasnoyarsk longer for a day to get the delayed baggage of the expedition and caught up with the group by the next steamer to Yeniseisk. The Yenisei Museum attracted the interest of the travelers, especially its ethnographic collection. But M. Haviland noted that the museum's natural science collection was in disarray and represented dusty artifacts that were not classified and were exhibited without the indication of a location (Haviland, 1915: 14).

The life of the expedition at the first stage can also be traced from photographs taken by Marie Czaplicka, some of them were published in ethnographic journals and travel notes of the ethnographer presenting the conditions of the researchers' stay in the tundra (Fig. 2). 


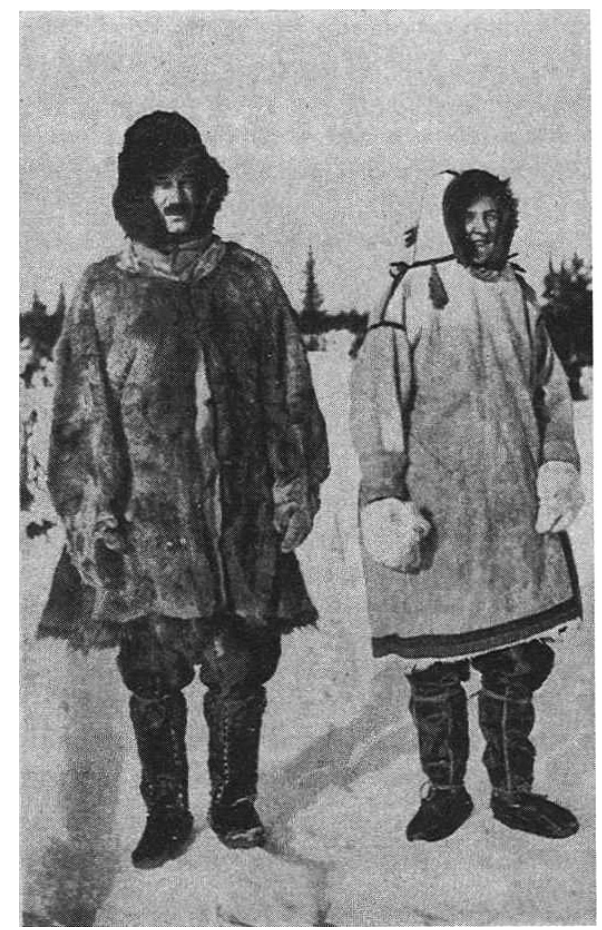

Fig. 2. Henry Hall and Marie Czaplicka in Tungus costumes in the Yenisei province in 1914

On the eve of the First World War, M. Haviland and D. Curtis returned to England through the Kara Sea (Haviland, 1915: 260). H. Hall and M. Czaplicka continued the second part of the journey from the Monastyrsky village to the nomadic Evenks and the Yakuts up to the Yessey. Subsequently, M. Czaplicka devoted the published travel notes to H. Hall, designating him as "a faithful companion" in this expedition (Czaplicka, 1916: 7).

The traveling to the north required serious preparation, therefore, studying the local peoples, the researchers themselves learned from them. "An indigenous person is extremely careful about his clothes for a winter trip, and he takes precautions to keep his feet safe, particularly to avoid frostbite.” (Czaplicka, 1916: 27). Similar principles were followed by the scientists. In addition, they respected indigenous peoples, ate their food, wore the same clothes, slept in their dwellings, and treated local people. Confidential relations made it possible to collect the necessary anthropological and ethnographic materials, as well as collections for English and American museums (Reshetov, 2010) (Fig. 3).

Returning from the north, the members of the expedition visited Krasnoyarsk and Minusinsk, where they intended to establish contacts with local museums, since they intended to return to Siberia for new works after the war (Klitsenko, 2016). Thus, the final 
part of the Yenisei expedition was held in the south of the province, including a visit to the Abakan steppe, the study of local archeology and ethnography, a visit to the Minusinsk museum. "The Minusinsk Museum, founded by Mr. Mart'ianov, political exiles, like most others who had the means to open museums, is one of the richest existing museums of local lore. The archeology and ethnography in the Minusinsk district are excellently represented in carefully arranged collections ..." (Czaplicka, 1916: 241).

There was a meeting of travelers with a Finnish archaeologist A.M. Talgren, who arrived the day before for archaeological research in the Minusinsk depression, in Minusinsk (Kuz'minyh, 2016: 163-170). The archive of A.M. Talgren has preserved a letter of Henry Hall from Krasnoyarsk about the archaeological collection of a Minusinsk merchant of antiquities, I.P. Tovostin, dated July 12, 1915, "Dear Mr. Talgren, I am afraid that I cannot accept your proposal for this collection. This is completely beyond my influence. But on my return to America (I will be in New York in Philadelphia, probably within a week), if you like, I can put the matter before Dr. Gordon, the director of the University Museum in Philadelphia, given your desire to have certain specimens for the Helsingfors Museum. Perhaps you will ask Mr. Tovostin

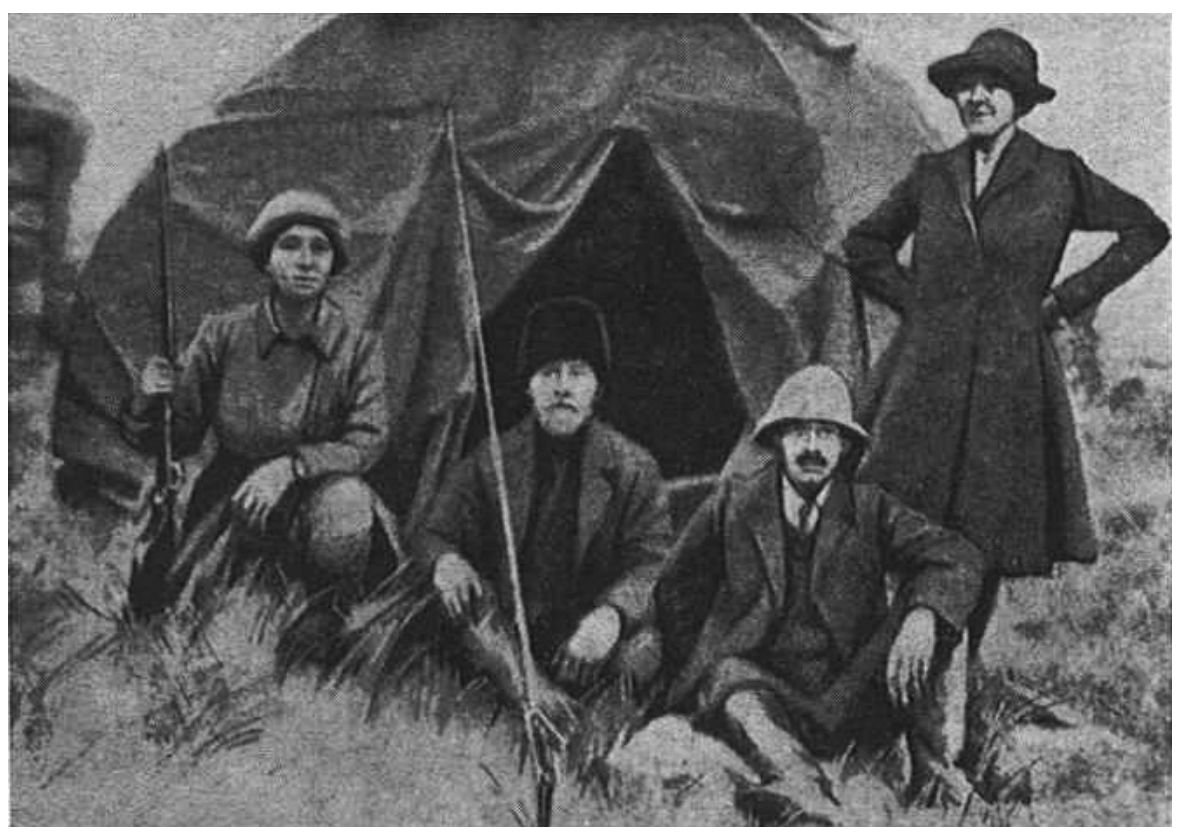

Fig. 3. Participants of the expedition: (to the right) Maud Haviland, Vasily Korobeinikov, Henry Hall, Dora Curtis in 1914

Severnyye arkhivy ekspeditsii [Northern archives of the expedition]. In Sodruzhestvo prosvetiteley krasnoyar'ya [Commonwealth of the Editors of Krasnoyaria]. Available at: http://www.intelsiberia.com/ severnye-arhivy 
to keep the offer in force until I contact you in Helsingfors, where, I believe, you will have been by the time my letter reaches you. This, of course, is not a very suitable proposal, but, I'm afraid, the only thing that can be done in the circumstances.

The day after tomorrow we are leaving Krasnoyarsk. If there's anything I can do for you in America, please let me know. Miss Chaplicka thanks you for your message and asks about you, kindly remembering you.

With deepest respect,

H.U. Hall.

P.S. Miss Chaplicka is thinking about the opportunity to offer to join the purchase of this collection in England. Could you be kind enough to send photos of the collection as soon as possible, indicating the copies that you could offer, so that Miss Chaplitzka enlisted the support of Dr. Aternberg from the Academy of Sciences?". H.U. Hall (Pis'mo G.A. Kholla A.M. Tal'grenu, 1915: 230.4)1.

Such a collection required completely different means. In addition, during studies in the North, M. Czaplicka and H. Hall had already made extensive collections of necessary materials characterizing everyday life, family forms, marriage, family relations, samples of various utensils, tools, tales and songs of foreigners. They also made up to 600 anthropological measurements of different aliens from 21 to 45 years old (K izucheniiu Sibiri, 1915: 1-2).

Several collections were formed from the completed collections, including the Asian collection in ethnography for the Pitt Rivers Museum of Ethnography and Archeology, and the botanical cherbarium, subsequently transferred to Fielding-Drews herbarium of the University of Oxford (Account of the Herbarium, 1897: 24-25).

In addition, Marie prepared several hundred of photos of the inhabitants of Siberia, a lot of measurements and notes. The Museum of Oxford University, dedicated to ethnography and archeology (the Pitt Rivers Museum), stores about 300 photos and negatives of Marie Czaplicka made during the Yenisei expedition depicting representatives of indigenous peoples, among which are group pictures, family pictures and images of single people, which are different from the pictures of shamans. Many of them depict reindeer, sledges, dwellings, landscapes of the tundra, Yenisei, cities, churches, the expedition members themselves, but many images are difficult to identify, although there are certain portraits of Siberians, for example Mikhail Suslov. There are several images of the barrows of the Abakan steppe, but they differ in dating:

\footnotetext{
The authors are grateful to Sergei Vladimirovich Kuzminykh (Institute of Archeology of the Russian Academy of Sciences, Moscow) for the provided archival materials.
} 
1912 and 1914-1915, it is possible that some photographs were acquired in Minusinsk, along with archaeological items, including a bronze dagger and knives, while a chisel, an ax, buttons, a whorl and iron tips were obtained from the Minusinsk Museum. In total, the Pitt Rivers Museum stores 193 items that characterize the way of life, occupation, culture, traditions of the indigenous peoples of the Yenisei North. There are also several archeological objects from Krasnoyarsk, representing ornaments. But a number of artifacts, as well as photographs, are not identified and do not have images in the museum's electronic collection (The Pitt Rivers Museum...).

The Museum of Pennsylvania contains 98 items of the Siberian collection of Henry Hall from the Yenisei expedition, particularly from the valley of the Lower and Middle Yenisei, Turukhansk, Novoturukhansk, the Ilimpiyskiy Tundra, Lake Essey, Minusinsk and the district, including arrows and a bow, knives, adzes, daggers, a flask, bags, aprons, tubes, snuffboxes, belts, bandoliers, bracelets, drums, gloves, a fur coat, coats, belts, carvings, hairdressing tools, jewelry, ornaments, pendants, napkins, mittens, rings, glasses, spoons, trousers and other attributes of northern peoples (The Penn Museum...).

The museum archive of the University of Pennsylvania stores letters, notes, research notes, reports, printed materials and photographs of Henry Hall. His reviews, notes and reviews in different years were published in the museum magazine and the Geographical Review magazine (Maizik, 2017: 69). Unfortunately, a significant part of the archives and diaries of the expedition is considered irretrievably lost.

In the village of Monastyrsky the expedition members got acquainted with Ya.M. Sverdlov, who noted in his essay on the Turukhansk region (1915), on their arrangements and surveys the following thing, "The material was very rich, but it concerned exclusively the life of the foreigners, namely, the Tungus, the Yurakovs, the Dolgans, the Samoyeds, and, mainly the Tungus. No matter how valuable the materials collected by the last expedition are, they will, firstly, either be completely unknown to us, or will reach us only in extracts; secondly, they do not introduce you to the entire population of the region." (Sverdlov, 1957: 336). Indeed, not all the materials are available to Russian researchers, many need to be translated.

The news about the outbreak of the world war forced the researchers to return to Europe soon. Military events, then revolutions interrupted so many foreign expeditions in Siberia.

After returning to England, M. Czaplicka published the book "My Siberian Year" in Oxford, continued teaching at Oxford University, where she was the only 
woman with a doctorate degree. In 1920 she was elected a full member of the Royal Geographical Society (Reshetov, 2010). It seemed that the success of the expedition contributed to her scientific achievements and career. Marie published a number of works on the ethnography of Siberia, such as "The influence of the environment on the religious beliefs and practices of the Aborigines of North Asia" (1914), "Tribes of the Yenisei. The Oxford expedition" (1915), "Siberia and Siberians" (1916), "A Siberian colonist or a Siberian" (1916), "On the trail of the Tungus" (1917), "An exile in Siberia" (1918) and others (Kochkina, 2016: 83-97).

In 1918, Oxford published the first publication of her work "The Turks of Central Asia in History and at the Present Day". The monograph was repeatedly reprinted and became a classic work dedicated to the history of the Turkic peoples from ancient times to the beginning of the $20^{\text {th }}$ century. The author turns to the Siberian Expedition's own materials, collections of both foreign scientific societies and museums of St. Petersburg, Moscow, Tomsk, Krasnoyarsk, Minusinsk, and also to the works of scientists, in particular, to the works of the Siberian researchers, namely, I.T. Savenkova, A.P. Ermolaeva, A.V. Adrianova, I.P. Kuznetsov-Krasnoiarskii, N.M. Iadrintsev and others (Czaplicka, 1918: 241).

The study of M. Czaplicka differed from other works of orientalists, as one of the few conceptual works on the history of the region in the English historiography of the first half of the $20^{\text {th }}$ century, which in these decades was most represented by studies focused on particular problems (Laumulin, 2015: 113). The appearance of these works was greatly facilitated by the Yenisei expedition.

In 1919, Mary traveled to the United States to meet leading anthropologists, including Henry Hall, who in 1918 published an illustrated essay "Siberian Wilderness: Native Life on the Lower Yenisei". He paid special attention to the Turukhansk region, described its nature, climate, the development of the Northern Sea Route, the history of colonization, indigenous peoples, their occupations, housing, clothing, vehicles, customs, holidays, issues of cultural development, "The complete lack of affection for land, the free movement of all tribes, the unity of the conditions under which life was taking place, all circumstances testify to the tendency of a common unification of Arctic cultures. Nevertheless, with obvious superficial similarities, the features of faith and social rituals that have long been differentiated still remain. There is evidence of the determination of tribes, according to which they differed from one another, and their cultures inevitably mingled with each other" (Hall, 1918: 20).

Marie Czaplicka planned new expeditions, but the war interfered with these plans, and then it was followed by the problems with her work at university. She 
failed to renew contracts with Columbia, Bristol and Oxford universities, and in 1921 the young researcher committed suicide. In her will, she wished that all her works were transferred to Henry Hall for their completion (Maria Chaplitsa explores...).

Despite such an early departure, Marie Czaplicka managed to realize herself fully as a researcher of the peoples of the North and Central Asia. Today her works are still relevant. The books by M.A. Czaplicka became and still remain encyclopedias on the study of the indigenous peoples of Siberia, in particular, the "classical" Siberian shamanism, for Western scientists.

British and Polish researchers are increasingly turning to both the personality and the scientific heritage of M. Czaplicka. At the end of 2013, a graduate student of Oxford University, Janika Wieder, visited Krasnoyarsk to search for sources on M. Czaplicka's expedition and intended to repeat the path of the researcher, which was completed in 1914-1915. In December 2013, she took part in the Siberian Historical Forum with the report "The English ethnographer Marie Czaplicka: her expedition in 1914 to the north of the Yenisei province".

In Poland, Gražina Kubica, an employee of the Jagiellonian University in Cracow, published a monograph "Marie Czaplicka - gender, shamanism, peoples. Biography of the anthropologist [Marie Czaplicka - płeć, szamanizm, rasa. Biografia antropologiczna]".

It should be noted that archival materials about the stay of M. Czaplicka's expedition in the Yenisei province have not yet been revealed; only rare notes in periodicals can be found; the Krasnoyarsk Regional Museum of Local Lore keeps the book "Moi god v Sibiri [My Siberian Year]", which was received by the KORGO library from 1916 to 1920 , possibly sent by the author.

In many respects, thanks to the centenary of the Yenisei expedition, scientists from different countries drew attention to this personality. However, in Russia the results of field work by M. Czaplicka remain little known.

\section{References}

Account of the Herbarium of the University of Oxford (1897). London: Oxford at the Clarendon Press, pp. 24-25.

Czaplicka, M.A. (1914). Aboriginal Siberia. A Study in Social Antropology. Oxford: Clarendoyn Press, 376 p.

Czaplicka, M.A. (1916). My Siberian Year. London, Miles \& Bonn, 316 p. 
Czaplicka, M.A. (1918). The Turks of Central Asia in History and at the Present Day. 241 p.

Ehrlich, L. (1917). Modern Poland, pp. 15-16.

Hall, H.U. (1918). A Siberian Wilderness: Native Life on the Lower Yenisei. In The Geographical Review, 5 (1), 1-21.

Haviland, M.D. (1915). A summer on the Yenesei (1914). London: Edward Arnold, $328 \mathrm{p}$.

K izucheniju Sibiri [To the study of Siberia] (1915). In Sibirskaja zhizn' [Siberian Life]. Tomsk, 98, 1-2.

Klitsenko, Ju.V. (2014). Odin god v Sibiri: k 100-letiju enisejskoj jekspedicii Marii Chaplickoj [One year in Siberia: to the $100^{\text {th }}$ anniversary of the Enisey expedition by Maria Czaplicka]. In Oficial'nyj sajt "Sibirskaja zaimka” [Siberian Zaimka]. Available at: http://zaimka.ru/klitsenko-czaplicka/

Klitsenko, Ju.V. (2016). Stat'i Sverdlova o enisejskoj jekspedicii Marii Chaplickoj [Articles of Sverdlov on the Enisey expedition of Maria Czaplicka]. In Oficial'nyj sajt "Sibirskaja zaimka" [Siberian Zaimka]. Available at: http://zaimka.ru/klitsenkosverdlov/

Kochkina, E.I., Vdovin, A.S. (2016.) "V stranu budushhego": iz istorii izuchenija severa Enisejskoj gubernii zarubezhnymi issledovateljami v nachale XX v. ["In the country of the future": from the history of the study of the north of the Yenisei province by foreign researchers in the early XX]. In Enisejskij Sever: istorija i sovremennost' [The Yenisei North: History and Modernity]. Ed. col. A.S. Vdovin. Krasnoyarsk: Krasnoyarsk State Pedagogical University named after V.P. Astafiev, 2, 83-97.

Kubica, G. (2015). Maria Czaplicka - płeć, szamanizm, rasa. Biografia antropologiczna [Marija Chaplickaja - plec', shamanism, race. Bjografija antropoljogichna]. Wydawnictwo Uniwersytetu Jagiellońskiego [Vydavnictvo Universytetu Jagel'ljon'skego], Kraków, 472 p. (in Polish)

Kuz'minyh, S.V., Vdovin, A.S., Kochkina, E.I. (2016). K stoletiju jekspedicii A.M. Tal'grena $\mathrm{v}$ Enisejskuju guberniju [By the centenary of the expedition of A.M. Tallgren in the Yenisei province]. In Sbornik materialov $V$ mezhregional'nyh kraevedcheskih chtenij, posvjashhennyh Leonidu Romanovichu Kyzlasovu [Collection of materials of $V$ interregional regional studies readings dedicated to Leonid Romanovich Kyzlasov]. Abakan: Khakass book publishing house, pp. 163-170.

Laumulin, M.T.(2015). Istorija Kazahstanai Central'noj Azii vmirovojorientalistike (k 550-letiju Kazahskogo hanstva) [The history of Kazakhstan and Central Asia in 
the world Orientalism (to the 550th anniversary of the Kazakh Khanate)]. Astana: KISI, 1, 416.

Lowie, R.H. (1918). Book reviews. In American Anthropologist, 325-326.

Majzik (Kochkina), E.I. (2017). Genri Holl - amerikanskij issledovatel' Enisejskoj gubernii [Henry Hall is American researcher of the Yenisei province]. In Mezhdisciplinarnye issledovanija $v$ arheologii, jetnografii $i$ istorii Sibiri: materialy Mezhdunarodnoj nauchnoj konferencii, posvjashhennoj 125-letiju so dnja rozhdenija uchenogo $i$ obshhestvennogo dejatelja Nikolaja Konstantinovicha Aujerbaha (1892-1930). Krasnojarsk, 27-30 sentjabrja 2017 g. [Interdisciplinary researches in archeology, ethnography and history of Siberia: materials of the International scientific conference devoted to the 125th anniversary of the birth of the scientist and public figure of Nikolai Konstantinovich Auerbach (1892-1930). Krasnoyarsk, September 2730, 2017]. Sv. Ed. A.S. Vdovin, N.P. Makarov; Ed. col. Krasnojarsk, pp. 69-71.

Maria Czaplicka (M.A. Чаплицка) odkrywczyni Syberii i syberyjskiego szamanizmu [Maria Chaplitsa explores Siberian and Siberian shamanism]. In Oficjalna strona Czesława Białczyńskiego [Oficial'nyj sajt Cheslava Bjal'chinskogo]. Available at: https://bialczynski.pl/wielcy-polacy/maria-czaplicka-м-а-чаплицка-odkrywczynisyberii-i-syberyjskiego-szamanizmu/ (in Polish)

Pis'mo G.A. Holla A.M. Tal'grenu iz Krasnojarska [Letter from H.U. Hall to A.A. Tallgren from Krasnoyarsk] (1915). In Handwritten department of the National Library of Finland. Coll. 230.4.

Reshetov, M.A. (2010). Chaplickaja i ee stat'ja “zhizn' i dejatel'nost' N.N. MikluhoMaklaja" [Czaplicka and her article "The life and work of N.N. Miklouho-Maclay"] In Oficial'nyj sajt "Kunstkamera" [Cabinet of curiosities]. Available at: http://www. kunstkamera.ru/files/lib/978-5-88431-193-0/978-5-88431-193-0_03.pdf

Sverdlov, Ja.M. (1957). Izbrannye proizvedenija $v$ 3-h tomah [Selected works in 3 volumes]. Moscow: SIPL, Vol. 1. $336 \mathrm{p}$.

The Penn Museum. Available at: https://www.penn.museum/

The Pitt Rivers Museum Anthropology and World Archaeology. Available at: https://www.prm.ox.ac.uk/ 


\title{
Освоение Сибири: \\ Енисейская (Оксфордская) экспедиция \\ 1914-1915 гг.
}

\author{
Е.И. Майзик, А.С. Вдовин \\ Красноярский государственный педагогический \\ университет им. В.П. Астафьева \\ Россия, 660049, Красноярск, ул. Ады Лебедевой, 89
}

Исследование посвящено английскому исследователю коренных народов Енисейского Севера Марии Чаплицка и Генри Холлу, ставшему ее спутником и антропологом в Енисейской (Оксфордской) экспедиции. Будучи молодой польской девушкой, она отправилась в Сибирь в качестве руководителя экспедиции и в результате подготовила ценную книгу на эту тему. Чаплицка стала первой женщиной-преподавателем Оксфордского университета. Она работала в Лондоне и путешествовала по Сибири, проводя обширные полевые исследования в эпоху, когда женщины не занимались ни научными исследованиями, ни экспедициями. Она также была опытным фотографом. Личность Марии Чаплицка уникальна. Ее работы остаются актуальными. Иностранные ученые обращаются кее исследованиям более ста лет, но она малоизвестна в современной России. Хотя она родилась и прожила большую часть жизни в Российской империи, авторы обращаются к личности Марии Чаплицка и ее работам. Целью работы является определение значения исследований Енисейской экспедиции. Коллекции, собранные в ходе экспедиции, хранятся в Музее археологии и антропологии Пенсильванского университета и Оксфордском музее этнографии и археологии Питта Риверса и составляют около 600 предметов этнографии, археологии и изображений. Исследования Марии Чапличка являются вкладом в этнографию Сибири.

Ключевые слова: этнография, антропология, Енисейская экспедиция, коренные народы Сибири, Мария Чаплиика, Генри Холл.

Публикация выполнена при финансовой поддержке КГАУ «Красноярский краевой фонд поддержки научной и научно-технической деятельности» и РФФИ, проект № 16-1124009 а(p) - «Туруханский край: освоение и изучение в конце XVIII - начале XX в.»

Научная специальность: 07.00.00-исторические науки. 